\title{
HISTORI PEMBERLAKUAN PERADILAN AGAMA ERA KERAJAAN ISLAM DAN PENJAJAHAN DI INDONESIA
}

\author{
Faisal \\ faisal_alfaerah@yahoo.com \\ Dosen Fakultas Syariah IAIN Langsa
}

\begin{abstract}
Abtract. The journey of the Religious Courts that has been passed in such a long period of time means that we are talking about the past, namely the history of the Religious Courts. With the entry of Islam into Indonesia, which for the first time in the first century Hijri $(1 \mathrm{H} /$ 7 AD) brought directly from Arabia by merchants from Mecca and Medina, the community began to implement the teachings and rules of Islamic religion in everyday life. The Religious Court is one of the Special Courts under the authority of the Supreme Court as the highest court in the Republic of Indonesia. As an Islamic Judiciary that had been established long before Indonesia's independence, the Religious Courts certainly could not be separated from the changes that occurred considering the reign of the Government of Indonesia had been held by various people with different backgrounds, politics and goals, surely it would have an impact on the existence Religious Courts both materially and immaterially, including during the Dutch and Japanese colonial rule in Indonesia.
\end{abstract}

Abtsrak.Perjalanan Peradilan Agama yang telah dilalui dalam rentang waktu yang demikian panjang berarti kita berbicara tentang masa lalu yakni sejarah Peradilan Agama. Dengan masuknya agama Islam ke Indonesia yang untuk pertama kali pada abad pertama hijriah (1 H/7 M) yang di bawa langsung dari arab oleh saudagar-saudagar dari mekah dan madinah, masyarakat mulai melaksanakan ajaran dan aturan agama Islam dalam kehidupan sehari-hari. Peradilan Agama adalah salah satu dari Peradilan Khusus yang berada dibawah kekuasaan Mahkamah Agung selaku peradilan tertinggi di Republik Indonesia ini. Sebagai Peradilan Islam yang telah berdiri sejak jauh sebelum Indonesia merdeka, tentulah Peradilan Agama ini tak terlepas dari perubahan-perubahan yang terjadi mengingat tampuk Pemerintahan Indonesia pernah dipegang oleh berbagai macam orang dengan latarbelakang, politik dan tujuan yang berbeda, tentulah hal tersebut membawa dampak terhadap keberadaan Peradilan Agama baik secara material maupun immaterial, termasuk pada Masa Pemerintahan Penjajahan Belanda dan Jepang di Indonesia.

Kata Kunci: Masa Kerajaan Islam, Penjajahan Belanda Dan Jepang, Peradilan Agama

\section{Pendahuluan}

Peradilan merupakan suatu sistim atau proses penegakan hukum dan keadilan. Ini berarti bahwa peradilan merupakan suatu prosesuntuk menegakkan hukum dan memberikan keadilan melalui pengadilan. Peradilan
Islam di Indonesia yaitu menyelesaikan jenis perkara menurut agama Islam. Dirangkaikannya kata peradilan Islam dengan di Indonesia adalah jenis perkara yang di adili tidak lah mencakup segala macam perkara menurut peradilan Islam secara universal. Peradilan agama adalah 
peradilan Islam yang telah di sesuaikan dengan keadaan di Indonesia.

Dapat di simpulkan bahwa Peradilan Agama adalah salah satu dari Peradilan Negara Indonesia yang sah, yang bersifat peradilan khusus, yang berwenang dalam jenis perkara perdata Islam tertentu, bagi orang-orang Islam di Indonesia. Peradilan agama adalah sebutan (titelateur) resmi bagi salah satu di antara empat lingkungan peradilan negara atau kekuasaan kehakiman yang sah di Indonesia. Tiga lingkungan peradilan negara lain nya adalah Peradilan Umum, Peradilan Militer, dan Peradilan Tata Usaha Negara. ${ }^{1}$

Periodisasi peradilan Islam di Indonesia sebelum datangnya pemerintahan kolonial (belanda) yang di sepakati para ahli terbagi tiga periode, yaitu:

\section{Periode Tahkim}

Pada awal masa Islam datang ke Indonesia, komunitas Islam sangat sedikit dan pemeluk Islam masih belum mengetahui tentang hal-hal yang berhubungan dengan hukum Islam. Bila timbul permasalahan, mereka menunjuk seseorang yang di pandang ahli untuk menyelesaikan nya. Apapun keputusan nya yang akan di jatuhkan oleh orang yang di tunjuk itu kedua nya harus taat mematuhinya itu.

\section{Periode Ahl Al halil wa al 'Aqdi}

Setelah kelompok-kelompok masyarakat Islam terbentuk dan mampu mengatur tata kehidupan sendiri, pelaksanaan kekuasaan kehakiman di laksanakan dengan jalan

\footnotetext{
1 Rasyid Roihan, Hukum Acara Peradilan Agama (Jakarta: PT Raja Grafindo persada, 2000), h. 5-6
}

mengangkat Ahl al-hal wa al 'Aqdi. Yaitu orang-orang yang terpercaya dan luas pengetahuan nya untuk menjadi sesepuh masyarakat.

\section{Periode Tauliah}

Setelah terbentuknya kerajaankerajaan Islam di Indonesia, pengangkatan hakim di laksanakan dengan cara tauliah dari imam, atau pelimpahan wewenang dari sultan selaku kepala negara. Kepala negara selaku wali al amri mempunyai wewenang mengangkat orang-orang yang telah memenuhi syarat tertentu untuk menjadi hakim di wilayah kerajaan yang di tentukan oleh kepala negara atau sultan. ${ }^{2}$

\section{Peradilan Pada Masa Kesultanan Islam}

Sebenarnya sebelum Indonesia datang ke Indonesia, di negeri ini telah di jumpai dua macam peradilan, yakni peradilan pradata dan peradilan padu, peradilan pradata mengurus masalahmasalah perkara yang menjadi urusan raja sedangkan peradilan padu mengurus masalah yang tidak menjadi wewenang raja. Pengadilan perdata bila diperhatikan dari segi materi hukum nya bersumber hukum hindu yang terdapat dalam papakem atau kitab hukum sehingga menjadi hukum tertulis, sementara pengadilan padu berdasarkan pada hukum Indonesia asli yang tidak tertulis.

Sejalan dengan laju perkembangan masyarakat muslim ketika itu kemudian masyarakat bertahkim kepada seseorang yang di anggap bisa memberikan jalan tengah dan penyelesaian hukum, seperti bertahkim kepada ulama/muballiqh. Jadi hukum Islam ketika itu sebagai hukum

\footnotetext{
${ }^{2}$ Alaiddin Koto, Sejarah Peradilan Islam (Jakarta: Rajawali Pers. 2012), h.191-195
} 
yang hidup di tengah-tengah masyarakat (the living law). Ketika perkembangan masyarakat semakin berkembang, tahkim beralih kepada bentuk pelimpahan wewenang kepada ablu balli wa al aqdi.

\section{Pada Masa Kerajaan Aceh}

Sewaktu Marcopolo singgah di peureulak pada tahun 1292, ia mendapatkan Peureulak merupakan sebuah kota Islam. Namun, tidak disebutsebut adanya raja atau sultan, pelaksanaan hukum Islam di dasarkan pada tauliyah oleh ahlu halli wa al aqdi. Sementara di Kota Samudera Pasai ada seorang raja atau sultan yang pertama, yaitu Sultan Malik As Salih (wafat 696 H/1297 M) yang telah memberikan bentuk tauliyah kepada hakim atau qadli dalam pelaksanaan hukum Islam.

Peureulak merupakan daerah pertama yang memeluk Islam, namun Samudera Pasai paling akhir di banding dengan Peureulak yang menerima Islam sebelum 1282 M, kendati pada 1292 M, hal ini belum diamati oleh Marcopolo. Dari data ini setidaknya dapat di katakan bahwa awal pengalaman tauliyah dari ahlu halli wa al aqdi paling cepat pada tahun 1282 sebelum Marcopolo singgah 1292 M di Peureulak. ${ }^{3}$

Setelah kerajaan Samudera Pasai ditaklukan Portugis sekitar tahun $1521 \mathrm{M}$, kerajaan itu berada di bawah pengaruh kesultanan Aceh yang berpusat di Banda Aceh Darussalam. Kekentalan pengaruh ajaran Islam pada masyarakat Aceh ini tidak hanya terjadi pada masa-masa kerajaan saja, tetapi juga terasa hingga sekarang. Mazhab hukum Islam yang

\footnotetext{
${ }^{3}$ Abdul Halim, Peradilan Agama dalam Politik Hukum di Indonesia, (Jakarta: PT Raja Grafindo Persada, 2002), h.39-41
}

berkembang di kerajaan Aceh adalah Mazhab Syafi'i yang pada masa pemerintahan Sultan Iskandar Muda memiliki seseorang mufti yang terkemuka bernama Syekh Abdur Rauf Singkil. Sultan Iskandar Muda adalah raja yang paling kokoh menjalankan aturan syariat tanpa pandang bulu terhadap siapa pun, Sultan Iskandar Muda pernah memberlakukan hukum rajam terhadap putranya sendiri yang bernama Meurah Pupok yang berzina dengan istri seorang perwira. Sultan Iskandar Muda berkata; "mati anak ada makamnya, mati hukum kemana hendak di cari". 4

Di Aceh, sistem peradilan yang berdasarkan hukum Islam menyatu dengan peradilan negeri, yang mempunyai tingkatan-tingkatan; tingkat pertama di laksanakan di tingkat kampung yang di pimpin Geuchik. Pengadilan ini hanya menangani perkara-perkara yang tergolong ringan, sedangkan perkaraperkara berat di selesaikan oleh Balai Hukum Mukim. Apabila yang berperkara tidak puas dengan putusan tingkat pertama, dapat mengajukan banding ke tingkat kedua yakni Oeloebalang. Bila pada pengadilan tingkat Oeloebalang juga di anggap tidak dapat memenuhi keinginan pencari keadilan, dapat mengajukan banding ke pengadilan tingkat ketiga yang di sebut Panglima Sagoe. Seandainya keputusan Panglima Sagoe tidak memuaskan, masih dapat mengajukan banding kepada Sultan yang pelaksanaannya oleh Mahkamah Agung.

Sistem peradilan di Aceh sangat jelas menunjukan hirarki dan kekuasaan absolutnya, hanya saja sumber tersebut tidak menggambarkan kekuasaan

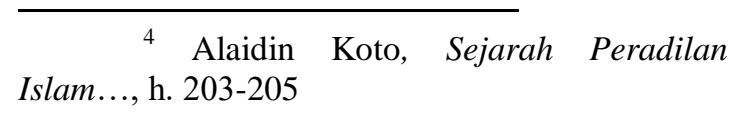


relatifnya (wilayah), sehingga mengalami kesulitan untuk di bandingkan dengan susunan Peradilan Agama yang ada sekarang ini. Tetapi setidaknya dapat di gambarkan bahwa kompetensi relatif pengadilan di Aceh tersebut mengikuti pada luas dan batas kampung di tingkat pertama, di tingkat kedua yakni Oeloebalang yang mewilayahi himpunan beberapa kampung, sekarang bisa di banding dengan kecamatan atau mungkin lebih tepat seperti Nagari di Minangkabau, tingkat Panglima Sagoe wilayah kekuasaannya beberapa Kecamatan atau Nagari, sedang Mahkamah Agungnya adalah Malikul Adil, Sri Paduka Tuan Bendhara Fakih, mempunyai relatif kompetensi mewilayah seluruh wilayah yang tunduk dibawah pemerintahan nya. ${ }^{5}$

\section{Pada Masa Kerajaan Mataram}

Kerajaan Islam yang paling berpengaruh di pulau jawa adalah Demak (yang kemudian di ganti oleh Mataram), Cirebon dan Banten. Di Indonesia Timur terdapat kerajaan Goa di Sulawesi Selatan dan Ternate yang pengaruhnya meluas hingga kepulauan Filipina. Di Sumatera yang ada kerajaan Aceh yang wilayahnya meliputi kawasan Melayu termasuk Malaysia dan sekitarnya. Perkembangan peradilan agama kerajaan mataram yang paling menonjol adalah pada masa Sultan Agung (1613-1645). Pada saat itu sebelum pengaruh Islam masuk dalam sistem peradilan, maka yang berkembang adalah ajaran Hindu yang memengaruhi sistem peradilan. Ketika itu perkara di bagi menjadi dua bagian, yaitu perkara yang menjadi urusan raja (perkaranya di sebut perkara perdata) dan perkara yang

\footnotetext{
Abdul Halim, Peradilan Agama Dalam Politik Hukum Di Indonesia..., h, 42
}

bukan urusan pengadilan raja (perkaranya di sebut Padu).

Dengan munculnya mataram menjadi kerajaan Islam, di bawah pemerintahan Sultan Agung mulai diadakan perubahan dalam sistem peradilan. Beliau memasukkan unsur-unsur hukum dan ajaran agama Islam dalam Peradilan Pradata dengan mengorbitkan orangorang yang berkompeten dalam bidang hukum Islam di lembaga peradilan. Sultan Agung mengambil kebijakan politik hukumnya dengan mengisi lembaga yang telah berkembang di tengah-tengah masyarakat dengan prinsip keIslamannya. Namun, setelah kondisi masyarakat di pandang siap dan paham dengan kebijakan yang di ambil Sultan Agung, maka

Banten sudah menjadi kota penting dan bersejarah sejak sebelum Islam datang ke Indonesia, yaitu pada saat banten berada dalam kekuasaan raja-raja sunda, bahkan mungkin sebelumnya. Banten adalah sebuah kerajaan Islam yang paling ketat melaksanakan hukum Islam dan tidak lagi di pengaruhi oleh hukum adat, Budha atau Hindu.

Di banten, pengadilan di susun menurut syariat Islam. Pada masa Sultan Hasanuddin memegang kekuasaan di banten hanya ada satu pengadilan yang dipimpin Qadhi sebagai hakim tunggal. Sedang di Cirebon, pengadilan di laksanakan oleh tujuh orang menteri yang mewakili tiga Sultan, yaitu Sultan Sepuh, Sultan Anom, dan Panembahan Cirebon. Semua aturan dan proses beracara dalam persidangan serta pengambilan sebuah keputusan merujuk kepada perundangundangan dan hukum Jawa. Kitab hukum yang menjadi rujukan adalah Papakem Cirebon. Kitab ini merupakan sebuah 
kompilasi dari hukum dan perundangundangan Jawa kuno, memuat kitab hukum raja niscaya, Undang-undang Mataram, Jaya Lengkara, Kontra Menawa, dan Adidullah. Namun, satu hal yang tidak bisa di pungkiri bahwa Papakem Cirebon dipengaruhi Hukum Islam.

Pada saat Sultan Ageng Ttirtayasa berkuasa (1651-1680), hukum Islam sudah di berlakukan secara sempurna. Hukum potong tangan bagi pencuri dengan memotong tangan kanan, kaki kiri seterusnya sudah di berlakukan bagi pencurian dengan nilai 1 gram emas. Sejarah Banten menyebutkan bahwa Syaikh tertinggi bergelar Kyai Ali atau Ki Ali yang kemudian di kenal dengan istilah Qadhi. Posisi Qadhi ini pada awal nya dijabat oleh seorang ulama dari Makkah, tetapi mulai tahun 1650 dan awal 1651 para qadhi sudah mulai di jabat oleh para bangsawan Banten.

\section{Pada Masa Kerajaan Islam di Sulawesi}

Di Sulawesi integrasi ajaran Islam dan lembaga-lembaganya dalam pemerintahan kerajaan dan adat lebih lancar karena peranan raja. Di sulawesi, kerajaan yang mula-mula menerima Islam dengan resmi adalah Kerajaan Tallo di Sulawesi Selatan. Kemudian menyusul Kerajaan Gowa yang muncul sebagai kerajaan terkuat dan mempunyai pengaruh di kalangan masyarakatnya. Melalui kekuasaan politik dalam struktur kerajaan di tempatkan parewa syara' (pejabat syariat) yang berkedudukan sama dengan parewa adek (pejabat adek) yang sebelum datangnya Islam telah ada. Parewa Syara' di pimpin oleh kali (Kadli), yaitu pejabat tertinggi dalam syariat Islam yang berkedudukan di pusat kerajaan. Di masing-masing Paleli diangkat pejabat bahwan yang di sebut imam serta di bantu oleh seorang khatib dan seorang bilal. Para kadi dan pejabat urusan ini di berikan gaji yang di ambilkan dari zakat fitrah, zakat harta, sedekah idul fitri dan idul adha, kenduri kerajaan, penyelenggaraan mayat dan penyelenggaraan pernikahan. Hal ini terjadi pada saat pemerintahan raja Gowa XV (1637-1653) ketika Malikus Said berkuasa. Sebelumnya raja goa sendiri yang menjadi hakim agama Islam.

Sementara itu di beberapa wilayah lain, seperti Kalimantan Selatan dan Timur, dan tempat-tempat lain, para hakim agama diangkat penguasa setempat. Di daerah-daerah lain, seperti Sumatera Utara, tidak ada kedudukan tersendiri bagi penyelenggaraan Peradilan Islam. Para pejabat agama langsung melaksanakan tugas-tugas peradilan, sebagaimana ditemukan di Palembang. Pengadilan agama yang di pimpin pangeran penghulu merupakan bagian dari struktur pemerintahan, di samping Pengadilan Syahbandar dan Pengadilan Patih. Di Pengadilan Syahbandar perkara di putus dengan berpedoman kepada hukum Islam dan ajaran Qur'an, sedangkan di Pengadilan Patih perkara di putus dengan berpedoman hukum adat. ${ }^{6}$

\section{Peradilan Islam Pada Masa Pendudukan Jepang}

Pada tahun 1942 Indonesia diduduki oleh Jepang. Pergeseran otoritas jajahan Jepang membawa pada perubahan yang besar bagi masyarakat Indonesia. Perbedaan yang fundamental antara

6 Abdul Halim, Peradilan Agama Dalam Politik Hukum Di Indonesia..., h. 45. 
imperialisme Jepang dengan imperialisme barat terletak pada karakter militernya, pemerintah militer Jepang yang menguasai Indonesia pada gilirannya memegang semua urusan pemerintahan kolonial.

Akibatnya pemerintah militer Jepang harus memikul tanggung jawab atas semua permasalahan hukum dan administrasi, suatu peran yang tidak jauh berbeda yang sudah dialami oleh Belanda sebelumnya. Penjajah Jepang yang memodifikasi beberapa bangunan struktural, memilih untuk tidak terlalu merubah beberapa hukum dan peraturan yang ada, demi kemudahan admistrasi, sebagaimana Belanda pada masa-masa awal penjajahannya, rezim Jepang sekarang mempertahankan bahwa adat istiadat lokal, praktik-praktik kebiasaan, dan agama tidak boleh dicampur tangani oleh pemerintah untuk sementara waktu dan hal-hal yang berhubungan dengan urusan penduduk sipil, adat, dan hukum sosial mereka harus dihormati, dan pengaturan yang khusus diperlukan dalam rangka untuk mencegah munculnya segala bentuk perlawanan dan oposisi yang tidak diinginkan.

Secara teoritis pemerintahan Jepang pada waktu itu berusaha untuk membuat pemisahan simbol secara total dengan pemerintahan Belanda. Simbol kolonial yang menandakan pemerintah Belanda dihapuskan, selain itu pergerakan-pergerakan yang pada masa penjajahan Belanda aktif pada masa pemerintahan Jepang secara tegas dilarang. Tidak seperti pemerintahan Belanda yang membuat sentralisasi administrasi di wilayah kekuasaanya di Indonesia, Jepang justru membagi wilayah Indonesia ke dalam tiga zona administrasi, yaitu:

a. Di Jakarta untuk mengatur Jawa dan Madura.

b. Di Singapura yang mengatur Sumatera.

c. Komando Angkatan Laut di Makassar yang mengatur keseluruhan Nusantara di luar tiga pulau yang telah diatur di atas. ${ }^{7}$

Sebagai akibat dari pengurangan yang drastis dari jumlah para pegawai Belanda dalam kantor-kantor pemerintahan, perubahan dalam organisasi peradilan juga harus terjadi. Pada tanggal 29 April 1942 pemerintahan bala tentara Dai Nippon mengeluarkan UU No 14 Tahun 1942 tentang Pengadilan Bala tentara Dai Nippon yang isinya bahwa Pemerintahan Jawa mengeluarkan beberapa aturan yang dirancang untuk melarang transformasi lembaga peradilan. Sebagai hasilnya, lembaga peradilan yang sekuler didirikan dimana bentuk peradilan lama diubah namanya dari bahasa Belanda kepada bahasa Jepang. Adapun susunan lembaga peradilan pada masa pendudukan Jepang adalah sebagai berikut :9

1. Tihoo Hooin yang berasal dari Landraad (Pengadilan Negeri).

2. Keizai Hooin yang berasal dari Landgerecht (Pengadilan Kepolisian)

3. Kein Hoin yang berasal dari Regetschapsgerecht (Pengadilan Kabupaten)

7 Jazuni,Legislasi Hukum Nasional di Indonesia, (Bandung: PT Citra Aditya Bakti,2005), h.176-177

9 Ibid, h. 178 
4. Gun Hooin yang berasal dari Districtsge recht (Pengadilan Kewenangan)

5. Kaikoo Kooto Hooin yang berasal dari Hof voor Islamietische Zaken (Mahkamah Islam Tinggi)

6. Sooyoo Hooin yang berasal dari Priesterrad (Rapat Agama), dan

7. Gunsei Kensatu Kyoko terdiri dari Tihoo Kensatu Kyoko

(Kebijaksanaan Pengadilan Negeri) berasal dari Paket voor Landraden Sedangkan Hoogerechtshof (Saiko Hooin) diunifikasikan menjadi satu lembaga peradilan yang melayani semua golongan masyarakat, sementara Residentiegerecht yang pada masa kolonial Belanda dikhususkan untuk mengadili golongan masyarakat Eropa pada masa penjajahan Jepang dihapuskan. Langkah unifikasi yang dilakukan pada masa penjajahan Jepang tidak hanya pada lembaga peradilan, tetapi juga dalam kantor kejaksaan. Jaksa yang bentukan terdahulu yang bertugas menurut prosedur Hukum Eropa, dan Jaksa Indonesia yang bekerja menurut Landraad, dikombinasikan kedalam Kensatu Kyoku. Jelas saja revolusi ini secara menggebu-gebu disambut oleh pejuang Muslim, terutama di Sumatra, yang senantiasa berharap untuk dapat menjatuhkan dominasi dari para tetua adat bersama pelindungnya, yaitu para pejabat Belanda.

\section{Peradilan Islam Pada Masa Penjajahan Belanda}

Dalam memahami potret perjalanan peradilan agama di Indonesia pada masa penjajahan, dapat di klasifikasi menjadi beberapa periode, yaitu era sebelum tahun 1882 pada masa kerajaan-kerajaan dan awal pendudukan belanda dan masa setelah belanda melancarkan politik hukum, setelah tahun 1882 sampai sekitar tahun 1937, dari sekitar tahun 1937 sampai pendudukan jepang, dan era setelah pendudukan jepang sampai Indonesia merdeka. Berikut ini akan dipaparkan secara detail perjalanan peradilan agama dalam periode-periode tersebut. $^{8}$

Sebelum belanda melancarkan politik hukumnya di Indonesia, hUkum Islam sebagai hukum yang berdiri sendiri telah mempunyai kedudukan yang kuat, baik di masyarakat maupun dalam peraturan perundang-undangan negara. Kerajaankerajaan islam yang pernah berdiri di Indonesia melaksanakan hukum islam dalam wilayah kekuasaannya masingmasing, dengan timbulnya komunitaskomunitas masyarakat Islam, maka kebutuhan akan lembaga peradilan yang memutus perkara berdasarkan hukum Islam makin diperlukan. Masyarakat pada masa kerajaan sampai awal kolonial belanda berkuasa dengan rela dan patuh serta tunduk mengikuti ajaran-ajaran Islam dalam berbagai dimensi kehidupan. Namun, keadaan itu kemudian menjadi terganggu dengan munculnya kolonialisme barat yang membawa misi tertrentu, mulai dari misi dagang, politik bahkan sampai misi kristenisasi.

Peradilan Agama di masa raja-raja Islam diselenggarakan oleh para penghulu, yaitu pejabat administrasi kemasjidan setempat. Sidang-sidang pengadilan agama pada masa itu biasanya berlangsung di serambi masjid, sehingga pengadilan agama sering pula disebut "pengadilan serambi". Kelembagaan

\footnotetext{
${ }^{8}$ Ibid., h. 43
} 
Peradilan Agama sebagai wadah, dan hukum Islam sebagai muatan isi pokok pegangan dalam menyelesaikan dan memutus perkara, tidak dapat dipisahkan. Pada masa kekuasaan kerajaan Islam lembaga peradilan agama termasuk bagian tak terpisahkan dengan pemerintahan umum, para ulama yang memegang kekuasaan dalam Peradilan Agama merupakan penghulu kraton yang mengurus keagamaan islam dalam semua aspek kehidupan. Kewenangan Peradilan Agama yang diselenggarakan oleh pihak keraton tersebut sangat luas mencakup perbagai permasalahan kemasyarakatan dan kerajaan.

Eksistensi Peradilan Agama yang di praktekkan tersebut merupakan bukti bahwa hukum Islam telah mampu melebur dengan hukum adat Indonesia, dan justru lebih bisa di terima oleh masyarakat. Hal ini tentu tidak terlepas dari keadaan sosial masyarakat saat itu yang mayoritasnya sudah memeluk agama Islam, selain itu kekuasaan pemerintahan kerajaan juga sangat mendukung aktifnya Peradilan Agama.

Setelah Belanda datang ke Indonesia dan mulai menjajah, dengan VOC yang merupakan badan persatuan pedagang yang sekaligus berfungsi sebagai badan pemerintahan mereka di Indonesia, keadaan sedikit berubah, mereka berusaha mengikis eksistensi Peradilan Agama yang diparaktekkan oleh warga pribumi melalui kebijakan-kebijakan mereka, pada tanggal 4 maret 1620 mereka mengeluarkan instruksi agar di semua daerah yag dikuasai VOC harus diberlakukan Hukum Sipil Belanda. usaha mereka ini tidak berhasil karena tidak diterima oleh masyarakat, dan bahkan mereka banyak yang melakukan perlawanan.

Pada tanggal 25 Mei 1760 berlakunya Hukum Islam di akui oleh VOC melalui Resolutie der Indische Regeling, yaitu berupa kumpulan aturan Hukum Perkawinan dan Hukum Kewarisan mebnurut Hukum Islam. Hal ini mungkin disebabkan karena sistem pemerintahan Belanda belum kuat kekuasaannya, dan juga idealisme serta fanatisme keberagamaan masyarakat Indonesia pada saat itu yang sangat kuat sekali, sehingga upaya pemerintah Belanda untuk menekan Peradilan Agama dan memasukkan hukum Eropa kurang berjalan lancar. ${ }^{9}$

Pada tahun 1830 pemerintahan belanda menempatkan peradilan agama di bawah pengawasan "landraad" (Pengadilan Negeri). Hanya lembaga Landraad yang berkuasa untuk memerintahkan pelaksanaan putusan Pengadilan Agama dalam bentuk "excecutoire verklaring" (pelaksanaan putusan), Pengadilan Agama tidak berwenang untuk menyita barang dan uang. $^{10}$

Dapat disimpulkan bahwa potret Peradilan Agama pada awal penjajahan Belanda sudah beroperasi secara maksimal, diakui dan diterapkan oleh kerajaan-kerajaan di Indonesia, walaupun belum diakui sebagai lembaga resmi yang independen oleh Belanda. hal ini bisa terjadi karena memang pengaruh Islam kuat sekali, kemudian pengakuan dan legitimasi yang diberikan oleh penguasa juga sangat mendorong berdirinya Peradilan Agama dan diakui

9 Basiq Djalil, Peradilan Agama Di Indonesia, (Jakarta: Kencana, 2010). h. 48

${ }^{10}$ Ibid., h. 52. 
keberadaannya serta aktualisasinya. Ini sesuai dengan Teori Living Law dan teori hukum ketatanegaraan. Peradilan Agama pada mulanya masih eksis dan memiliki peran penting pada masa awal penjajahan Belanda, ini karena sesuai dengan Teori Living Law hukum yang hidup di masyarakat dan yang mempengaruhi pola pikir mereka adalah hukum Islam, namun ketika belanda berkuasa dan melancarkan politik hukumnya, peradilan agama dengan hukum Islam yang diusungnya bersinggungan dengan hukum Eropa dan hukum adat, ketika terjadi gap semacam ini maka kebijakan penguasalah yang paling menentukan, pemerintah belanda dalam hal ini ingin menyingkirkan peradilan agama walaupun masyarakat mayoritas muslim, ini tentunya tidak lepas dari pertimbangan politik dari mereka, seperti terancamnya kekuasaan, ketakutan akan fanatisme yang berlebihan dari rakyat jajahan. $^{11}$

Lahirnya firman Raja Belanda (Koninklijk Besluit) tanggal 19 Januari 1882 Nomor 24, yang dimuat dalam Staatsblad 1882 No. 152 telah mengubah susunan dan status Peradilan Agama. serta pengakuan dan pengukuhan akan keberadaan Pengadilan Agama yang telah ada sebelumnya, ini adalah merupakan tonggak sejarah yang sangat penting bagi Peradilan Agama, dengan adanya Staatblad 1882 no.152 yang di keluarkan pada tanggal 1 Agustus 1882 ini, maka secara yuridis formal Peradilan Agama sebagai suatu badan peradilan yang terkait dengan sistem kenegaraan untuk pertama kali lahir di Indonesia.Adapun wewenang Pengadilan Agama yang disebut dengan "preisterraacf", menurut Noto Susanto

\footnotetext{
${ }^{11}$ Abdul Halim, Peradilan Agama Dalam Politik Hukum,....h. 59-61
}

(1963: 7) perkara-perkara itu umumnya meliputi: pernikahan, segala jenis perceraian, mahar, nafkah, keabsahan anak, perwalian, kewarisan, hibah, waqaf, shadaqah, dan baitul mal, yang semuanya erat dengan agama Islam,

Selain Peradilan Agama pada saat itu terdapat 5 buah tatanan peradilan, yaitu:

1. Peradilan Gubernemen, tersebar di seluruh daerah Hindia-Belanda

2. Peradilan Pribumi, tersebar di luar Jawa dan Madura, yaitu di Karesidenan Aceh, Tapanuli, Sumatera Barat, Jambi, Palembang, Bengkulu, Riau, Kalimantan Barat, Kalimantan Selatan dan Timur, Manado dan Sulawesi, Maluku, dan di pulau Lombok dari Karesidenan Bali dan Lombok.

3. Peradilan Swapraja, tersebar hamper di seluruh daerah swapraja, kecuali di Pakualaman dan Pontianak.

4. Peradilan Agama, tersebar di daerah-daerah tempat Peradilan Gubernemen, di daerah-daerah dan menjadi bagian dari Peradilan Pribumi, atau di daerah-daerah swapraja dan menjadi bagian dari peradilan swapraja.

5. Peradilan Desa, tersebar di daerahdaerah tempat berkedudukan Peradilan Gubernemen. Disamping itu ada juga Peradilan Desa yang merupakan bagian dari Peradilan Pribumi atau Peradilan Swapraja. ${ }^{12}$

Pengakuan hukum Islam yang berlaku bagi orang Indonesia pada waktu

12 Mushofa, Kepaniteraan Peradilan Agama, (Jakarta: Kencana, 2005). h. 95 
itu sangat dipengaruhi oleh pemikiran hukum sarjana barat L.W.C. Van De Berg, dia sebagai penasehat kerajaan Belanda adalah konseptor Staatblad 1882 no.152. Dia mengemukakan sebuah teori yang disebut teori "receptio in complexu", Teori ini digagas oleh Salomon Keyzer yang belakangan dikaitkan oleh Lodewijk Willem Christian van den Berg (1854-1927). Maksud teori ini, adalah "hukum mengikat agama yang dianut seseorang. Jika orang itu memeluk agama Islam, hukum Islamlah yang berlaku baginya. Dengan kata lain teori ini menyebut bagi rakyat pribumi yang berlaku bagi mereka adalah hukum agamanya, walaupun terjadi penyimpangan-penyimpangan dalam prakteknya".

Pada tahun 1937 munculah Staatsblad 1937 Nomor 116, dengan stanblaad ini berarti telah mengurangi kompentensi pengadilan agama di Jawa dan Madura daIam bidang perselisihan harta benda, yang berarti masalah wakaf dan waris harus diserahkan kepada pengadilan negeri, mereka (Pemerintah Kolonial Belanda) berdalih, bahwa dalam kenyataan kehidupan bermasyarakat, hukum Islam tidak mendalam pengaruhnya pada aturan-aturan kewarisan dalam keluarga Jawa dan Madura serta di tempat-tempat lain diseluruh Indonesia.

Wewenang Pengadilan Agama di Jawa dan Madura berdasarkan ketentuan baru pasal 2a Staatblad 1837 meliputi perkara-perkara sebagai berikut:

1. Perselisihan antar suami istri yang beragama Islam.

2. Perkara-perkara tentang: Nikah, Talak, Rujuk, dan Perceraian antara orang-orang yang beragama Islam yang memerlukan perantaraan hakim agama Islam.

3. Menyelenggarakan perceraian.

4. Menyatakan bahwa syarat untuk jatuhnya talak yang digantungkan (ta'liq al thalaq) telah ada.

5. Perkara mahar atau mas kawin.

6. Perkara tentang keperluan kehidupan isteri yang wajib diadakan oleh suami.

Teori receptio bertujuan untuk mengetahui peranan hukum Islam dengan mengedepankan hukum adat atau bahkan mengganti hukum Islam dengan hukum adat. Selain itu bertujuan untuk memperkuat pemerintah kolonial dan adanya kepentingan pemerintah kolonial dalam penyebaran agama kristen di wilayah Hindia Belanda.

Dengan ini pemerintah Belanda melegislasi Peradilan Agama, namun dengan terselubung bermaksud mematikan Peradilan Agama dengan cara sedikit demi sedikit mengurangi kewenangan serta membiarkan tanpa pembinaan. $^{13}$

\section{Penutup}

Dari uraian pembahasan di atas dapat di simpulkan bahwa sebelum Islam masuk ke nusantara, peradilan agama telah ada dan berkembang hingga datang nya Islam. Sifat Islam yang meniadakan tingkat atau kasta, maka semakin mudah Islam masuk ke dalam kerajaan-kerajaan. Sehingga segala aspek yang beraturan ajaran hindu, saat itu beralih menjadi ajaran Islam. Kemudian masyarakat mulai melaksanakan ajaran Islam. Oleh karena di kerajaan-kerajaan di Indonesia itu yang

\footnotetext{
${ }^{13}$ Abdul Halim, Peradilan Agama Dalam Politik Hukum Islam,...h. $71-72$
} 
berdaulat adalah raja (yang berkuasa mutlak) . maka kekuasaan mengadili pun ada pada tangan raja. Akan tetapi tidak dapat di sangkal pula bahwa di Indonesia tidak semua perkara diadili oleh raja dan bahwa di tiap-tiap kesatuan hukum tiaptiap kepala adat atau daerah menjadi hukum perdamaian.

Perubahan Perbedaan posisi serta wewenang Peradilan Agama dapat dibedakan berdasarkan periodesasi; Masa Peradilan agama saat pendudukan Jepang masih diakui sebagai lembaga peradilan formal. Wewenangnya tidak ada perubahan yang jelas, faktor yang mempengaruhi yaitu kebijakan Politik Jepang dan kelemahan posisi pemerintahan Jepang dan masa transisi yakni awal penjajahan Belanda sampai tahun 1882.

Perjalanan historisnya Peradilan Agama mengalami pasang surut dalam hal posisi dan kewenangannya, ini tidak lepas dari faktor keadaan politik dan kebijakan penguasa, keadaan sosio historis masyarakat, serta gap antara empat hukum yang tumbuh dan berkembang di Indonesia, hukum Islam, hukum adat, hukum darat Eropa (civil 05 . law), dan hukum kepulaun Eropa (common law).

\section{DAFTAR PUSTAKA}

Alaiddin Koto, Sejarah Peradilan Islam, Jakarta: Rajawali Pers. 2012.

Abdul Halim, Peradilan Agama dalam Politik Hukum di Indonesia, Jakarta: PT Raja Grafindo Persada, 2002.

Abdul Jamal, (Jurnal) Tipologi Peradilan Agama, Pada Masa Kerajaan Islam Nusantara, Jurnal Kependidikan PerKhasa Volume 3, Nomor 2, Oktober 2017.

Basiq Djalil, Peradilan Agama Di Indonesia, Jakarta: Kencana, 2010.

Jazuni,Legislasi Hukum Nasional di Indonesia, Bandung: PT Citra Aditya Bakti, 2005.

Rasyid Roihan, Hukum Acara Peradilan Agama, Jakarta: PT Raja Grafindo persada, 2000.

Mushofa, Kepaniteraan Peradilan Agama, Jakarta: Kencana, 20 